\title{
Molecular Characterization of Hairy Fleabane Using RAPD ${ }^{1}$
}

\author{
Caracterização Molecular de Buva por RAPD \\ SILVA, D.R.O. ${ }^{2}$, AGOSTINETTO, D. ${ }^{3}$, and VARGAS, L. ${ }^{4}$
}

\begin{abstract}
With the increase of glyphosate resistance evolution in hairy fleabane, the knowledge of genetic diversity is essential to assist in the weed management. The objective was to characterize the genetic diversity of glyphosate resistant Conyza species in Rio Grande do Sul. Hairy fleabane biotype seeds were collected in fields of glyphosate-resistant soybean, generating seedlings used for extracting DNA from the leaves to perform a genetic diversity analysis, using the RAPD technique. The DNA was used in polymerase chain reaction and DNA fragments were assessed for polymorphism bands in electrophoresis. Biotypes were identified as Conyza bonariensis and microcephala varieties. In molecular analysis, among 25 primers RAPD, eight were reproducible generating polymorphisms of high intensity for the separation of biotypes. Cluster analysis revealed five groups, which had a genetic similarity of $53 \%$. The results indicate that all known biotypes are of the same species, but exhibit different varieties. RAPD presents itself as an important tool for characterizing Conyza species.
\end{abstract}

Keywords: Conyza bonariensis, polymorphism, glyphosate, PCR.

\begin{abstract}
RESUMO - Com a evolução do aparecimento de casos de buva resistente ao glyphosate, o conhecimento da diversidade genética é importante para auxiliar no manejo dessa planta daninha. Assim, o objetivo deste estudo foi caracterizar a diversidade genética de plantas de Conyza spp. resistentes ao glyphosate ocorrentes no Rio Grande do Sul. Foram coletadas sementes de biótipos de buva em áreas de cultivo de soja geneticamente modificada resistente ao glyphosate, das quais foi extraido DNA das folhas para análise de diversidade genética, utilizando-se a técnica de RAPD. O DNA foi usado na reação de polimerase em cadeia, e os fragmentos de DNA foram avaliados quanto ao polimorfismo das bandas em eletroforese. Os biótipos foram identificados como Conyza bonariensis variedades bonariensis e microcephala. Na análise molecular dos 25 primers testados, oito apresentaram polimorfismos reprodutiveis e de alta intensidade para a separação dos biótipos. A análise de agrupamento revelou cinco grupos, os quais apresentaram similaridade genética de 53\%. Os resultados indicam que todos os biótipos identificados são da mesma espécie, porém apresentam variedade distinta. A técnica de RAPD apresenta-se como importante ferramenta para caracterização de espécies de Conyza.
\end{abstract}

Palavras-chave: Conyza bonariensis, polimorfismos, glyphosate, PCR.

\section{INTRODUCTION}

The genus Conyza Less. belongs to the subtribe Conyzinae and includes approximately 100 species of plants, which are distributed through almost the entire world. The species Conyza bonariensis is native from South
America, occurring mainly in Argentina, Brazil, Paraguay and Uruguay; however, it can occur in Europe. In Brazil, it is especially found in the south, south-west and central-west, infesting empty lots and perennial and annual crops and beside highways (Kissmann and Groth, 1999).

Recebido para publicação em 6.11.2015 e aprovado em 3.2.2016.

2 Universidade Federal de Santa Maria, campus Frederico Westphalen-RS, Brasil, <diecsonros@hotmail.com>; ${ }^{3}$ Universidade Federal de Pelotas, Pelotas-RS, Brasil; ${ }^{4}$ Embrapa Trigo, Passo Fundo-RS, Brasil. 
Species from the genus Conyza grow in disturbed environments and they are plants which possess a high ability to colonize other areas, due to their characteristics, especially the high production and dispersion of descendants; knowledge about the genetic diversity of weeds is an essential factor in order to execute a long term management program and prevent the emergence of other infested areas (Dekker, 1997).

The agricultural environment, with its disturbances, imposes selective pressure in weed communities that, inevitably, results in exchange of plant population in the environment (Owen, 2008). The quantity of herbicide mechanisms used in weed control in crops has reduced in the past years, mostly for the use of genetically modified crops, that are resistant to herbicides. In Brazil, those changes created ecological implications, inducing changes in weed communities, especially due to the evolution of resistant biotypes of hairy fleabane (Conyza sp.), sourgrass (Digitaria insularis) and Italian rye-grass (Lolium multiflorum) and/or the selection of tolerant species, such as the Mexican fireplant (Euphorbia heterophylla), the Benghal dayflower (Commelia benghalensis), Ipomeas sp. and the tropical Mexican clover (Richardia brasiliensis).

At large, weeds present high genetic variability among the plants in a population or between populations, with potential to adapt to the management used in their control (Holt and Hochberg, 1997), with the possibility of this population to present an elevated initial frequency of resistance alleles, contributing, in this way, to a rapid selection of biotypes to herbicide resistance (Vargas et al., 1999).

The advances in molecular studies, with development of PCR (Polymerase Chain Reaction), brought knowledge to the population genetics field, which allowed the evaluation of the genetic diversity directly in DNA level. The RAPD technique (Random Amplification of Polymorphic DNA) has been utilized in the weed science field, especially for the characterization and genetic similarity in weed populations; among the species that have been studied through RAPD markers are Conyza sumatrensis (Ren et al., 2010), Euphorbia heterophylla (Winkler et al., 2003),
Amaranthus spp. (RAY; ROY, 2009); Oryza granulata (Wu et al., 2004) and Bidens pilosa (Vidal et al., 2007).

The RAPD markers are produced through the randomized amplification of DNA segments with short oligonucleotide primers of arbitrary sequence (Williams et al., 1990). These markers can be used for taxonomical identification, relation, gene flow analysis and hybridization, among others (Lacerda et al., 2002). An advantage in this technique utilization is that there is no need of previous knowledge on the plant's genome.

With the breeding potential between species, it is expected for genetic diversity to be found among the Conyza populations in Rio Grande do Sul (Brazil), since the breeding between species from the genus Conyza impacts the appearance of intermediary phenotypes (Zelaya et al., 2007). Understanding the genetic diversity in plant populations can be useful in the management of weeds, especially if the genetic diversity results in different management answers. Hence, the objective of this study is to characterize the genetic diversity of Conyza spp. resistant to glyphosate and which occur in Rio Grande do Sul, through the RAPD markers technique.

\section{MATERIAL AND METHODS}

Seeds of hairy fleabane were collected from soybean crop in 390 sites in Rio Grande do Sul. Each site corresponded to seeds of one plant, identified as the plant which survived to the glyphosate treatment in the management of soybean RR. The collecting time of the hairy fleabane seeds coincided with the end of the soybean cycle, period where the infesting plants which survived the glyphosate treatment, presented mature seeds. The collected seeds were cleaned, identified, packaged in paper bags and stored in room temperature.

The collected hairy fleabane seeds were wetted in water for 48 hours and, afterwards, put to germinate in trays with soil. The trays were kept in type BOD growth chambers and, after the sprout, the seedlings were transplanted to vases with capacity for $500 \mathrm{~mL}$. To verify the resistance to glyphosate, the herbicide was applied in a $2.160 \mathrm{~g}$ e.a. ha-1 
dose, when the plants were in a development stage of two to four leaves. In the herbicide application, a costal pulverizer was used, pressured with $\mathrm{CO}_{2}$, equipped with flat and straight (110.015) nozzles, and low volume equivalent to $150 \mathrm{~L} \mathrm{ha}^{-1}$. The surviving plants were pre-selected according to morphological differences and, when in bloom, taken to identification at the Rural Vegetation Studies Laboratory, in the Botanical Department in the Federal University of Rio Grande do Sul.

For the molecular analysis of the plants, seeds from seven biotypes of hairy fleabane (Table 1) which survived to a $2.160 \mathrm{~g} \mathrm{e}^{\mathrm{a}} \mathrm{ha}^{-1}$ dose were put to germinate, in the same conditions described; when the plants exhibited around 20 leaves, they were conducted to the Plant Molecular Physiology Laboratory in the Botanical Department, in the Biology Institute of the Federal University of Pelotas.

The plant materials used for DNA extraction were young leaves from seven biotypes of hairy fleabane - adapted protocol from Doyle and Doyle (1987). Each sample was macerated with $900 \mu \mathrm{L}$ of the extraction buffer (CTAB 2\% + mercaptoethanol 1\%), followed by the incubation in water bath in $60{ }^{\circ} \mathrm{C}$ for 45 minutes. With the samples in room temperature, an equal volume $(900 \mu \mathrm{L})$ of chloroform/isoamyl alcohol (24:1) was added and agitated for 10 minutes. Subsequently, the samples were centrifuged in a microcentrifuge, at a speed of $13,000 \mathrm{rpm}$ for 8 minutes, and approximately $550 \mu \mathrm{L}$ of the supernatant were transferred to a new tube and added to the same volume $(550 \mu \mathrm{L})$ of ethanol $\left(-20^{\circ} \mathrm{C}\right)$, keeping the samples at $20^{\circ} \mathrm{C}$ for two hours, for DNA precipitation. Afterwards, the samples were centrifuged at 8,000 rpm for
5 minutes, eliminating the alcohol. Each pellet was washed with ethanol 70 and $100 \%$, dried in a laminar flow cabinet and dissolved with $100 \mu \mathrm{L}$ of TE $\mathrm{pH} 8.0$, containing $10 \mu \mathrm{L} \mathrm{mL}^{-1}$ of RNase, with following incubation at $37^{\circ} \mathrm{C}$ for one hour.

The DNA was quantified in agarose gel $1.0 \%$ and diluted to the final concentration of $20 \mathrm{ng}$, in order to be utilized in the polymerase chain reaction (PCR). The estimate of the DNA concentration was done based on the comparison of intensity of the bands with DNA ë pattern digested with Hind III enzyme.

Twenty five RAPD primers (Operon Technologies) were evaluated as to the polymorphism pattern generated (Table 2), being only those that generated a polymorphism in the biotypes of hairy fleabane subsequently utilized. The PCR reactions were held in a final volume of $25 \mu \mathrm{L}$ containing $10 \mu \mathrm{M}$ of primer, $2.5 \mathrm{mM}$ of $\mathrm{MgCl}_{2}, 2.5 \mathrm{mM}$ of each desoxyribonucleotide (dNTP), $2.5 \mu \mathrm{M}$ of buffer 10x, 1.25 of Taq polymerase (Ludwig) and $20 \mathrm{ng}$ of genomic DNA. The amplifications were done in a thermal cycler Icycler (Bio-Rad Laboratories, USA), with the following conditions: one cycle of $94{ }^{\circ} \mathrm{C}$ for 2 minutes and 30 seconds, $36^{\circ} \mathrm{C}$ for 30 seconds and $72{ }^{\circ} \mathrm{C}$ for 2 minutes; 21 cycles of $94^{\circ} \mathrm{C}$ for 2 seconds, $36^{\circ} \mathrm{C}$ for 15 seconds, $45^{\circ} \mathrm{C}$ for 15 seconds and $72{ }^{\circ} \mathrm{C}$ for 1 minute and 30 seconds; 19 cycles of $94{ }^{\circ} \mathrm{C}$ for 20 seconds, $36^{\circ} \mathrm{C}$ for 15 seconds, $45^{\circ} \mathrm{C}$ for 15 seconds and $72{ }^{\circ} \mathrm{C}$ for 2 minutes; and one cycle of $72{ }^{\circ} \mathrm{C}$ for 10 minutes.

The fragments from the PCR reactions were separated through agarose gel electrophoresis $2.0 \%$, afterwards, the bands were stained in ethidium bromide bath for 15 minutes and visualized with the aid of a blot documentor (E-BOX-100 - Vilber Lourmat).

Table 1 - Collection sites and biotypes of Conyza bonariensis collected in Rio Grande do Sul

\begin{tabular}{|l|c|l|}
\hline \multicolumn{1}{|c|}{ Site } & Number of biotypes & Biotypes \\
\hline Pelotas & 5 & Conyza bonariensis var. bonariensis \\
\hline Soledade & 51 & Conyza bonariensis var. bonariensis \\
\hline Guarani das Missões & 62 & Conyza bonariensis var. bonariensis \\
\hline Cruz Alta & 130 & Conyza bonariensis var. bonariensis \\
\hline Caçapava do Sul & 358 & Conyza bonariensis var. bonariensis \\
\hline São Sepé & 319 & Conyza bonariensis var. microcephala \\
\hline Piratini & 363 & Conyza bonariensis var. microcephala \\
\hline
\end{tabular}


Table 2 - RAPD primers sequence used in the genetic characterization of Conyza bonariensis

\begin{tabular}{|c|c|c|c|}
\hline Primer & Sequence & Primer & Sequence \\
\hline OPA-01 & CAGGCCCTTC & OPB-03 & CATCCCCCTG \\
\hline OPA-02 & TGCCGAGCTG & OPB-10 & CTGCTGGGAC \\
\hline OPA-03 & AGTCAGCCAC & OPB-19 & ACCCCCGAAG \\
\hline OPA-11 & CAATCGCCGT & OPB-20 & GGACCCTTAC \\
\hline OPA-17 & GACCGCTTGT & OPAP-04 & CTCTTGGGCT \\
\hline OPA-18 & AGGTGACCGT & OPAZ-04 & CCAGCCTCAG \\
\hline OPX-02 & TTCCGCCACC & OPAI-07 & ACGAGCATGG \\
\hline OPX-03 & TGGCGCAGTG & OPAM-11 & AGATGCGCGG \\
\hline OPX-07 & GAGCGAGGCT & OPAM-14 & TGGTTGCGGA \\
\hline OPAC-09 & AGAGCGTACC & OPAF-11 & ACTGGGCCTC \\
\hline OPAC-12 & GGCGAGTGTG & OPL-05 & ACGCAGGCAC \\
\hline OPAC-19 & AGTCCGCCTG & OPS-14 & AAAGGGGTCC \\
\hline OPC-17 & TTCCCCCCAG & & \\
\hline
\end{tabular}

The primers that showed reproducible and high intensity polymorphisms were selected and subsequently used in the characterization of the seven biotypes of hairy fleabane. With the data of presence (1) or absence (2) of bands, a similarity matrix was generated based on the Jaccard coefficient, used to obtain a dendrogram through the UPGMA method using the NTSYS - PC software. Also through this software, grouping data were used to calculate the cophenetic matrix, in order to verify the dendrogram's representativeness related to the similarity data, measured by the "r" correlation coefficient.

\section{RESULTS AND DISCUSSION}

All the biotypes were identified as belonging to the Conyza bonariensis species, although the existing variation was related to the variety, in which the existence of the varieties bonariensis and microcephala was verified (Table 1 ). The bonariensis variety may present $100 \mathrm{~cm}$ of height, while the microcephala can achieve $180 \mathrm{~cm}$ (Kissman and Groth, 1999); however, in a greenhouse environment, plants with approximately $250 \mathrm{~cm}$ were observed. Both varieties present some sort of stem, ramifications and leaves, and distinguish from one another through the inflorescence, where in the bonariensis present capitulums with $6-7 \mathrm{~mm}$, compared to pedicelled capitulums smaller than $6 \mathrm{~mm}$ in length of the microcephala variation. The achenes of the bonariensis variation are pubescent with $1.5-2 \mathrm{~mm}$ length, and the ones in microchephala are lacking piles and smaller than $1 \mathrm{~mm}$ (Entz and Paz, 1999).

Studies with the intention to identify glyphosate resistant Conyza species in Rio Grande do Sul also verified the occurrence of Conyza bonariensis, bonariensis and microcephala varieties (Guareschi et al., 2012). These authors, analyzing the cytogenetic characterization of the populations, verified the occurrence of tetraploid and pentaploid species. Paula et al. (2009) have found hexaploid Conyza bonariensis plants in the south of Rio Grande do Sul. In contrast, Zelaya et al. (2007) reported that the species Conyza canadensis and C. ramosissima are diploid plants.

Studies about the floristic composition in Rio Grande do Sul evinced that other Conyza species occur in the State. In the high flat regions of the State, important for its soybean production and where the biotypes of glyphosate resistant hairy fleabane occur, species of $C$. bonariensis microcephala varieties, C. chilensis and C. sumatrensis were observed. (Schneider and Irgang, 2005; Santos et al., 2014). Guareschi et al. (2012) verified the presence of the microcephala varieties of 
C. Bonariensis, with the occurrence of a complex polyploidy arrangement among these found varieties. In the Santo Antônio da Patrulha region, C. primulifolia was found (Ferreira and Satubal, 2009). In the Campanha do Rio Grande do Sul region, a vast variety of species of Conyza were found in different habitats and abundances; among the found species, are C. blakei, C. bonariensis, C. floribunda, C. lorentzii, C. notobellidiastrum and C. primulifolia (Ritter and Baptista, 2005).

The Conyza sp. plants present a limited gene flow, once the pollen liberation is previous to the opening of the capitulums, however, the cross-fertilization can be of $9 \%$ in controlled conditions and, in natural conditions, it's around 2 to $4 \%$ (Zelaya et al., 2007). With the breeding potential between species, genetic diversity and phenotypic variability are expected to be found among plants, which can result in a misplaced identification of the species. This phenotypic variation may be due to the hybridization between the species, which has shown the formation of intermediary phenotypes regarding morphologic characters (Zelaya et al., 2007; Pagnoncelli et al., 2012). Another important factor related to the breeding between species is the increase in the herbicide resistance factor that the progenies can exhibit (Zelaya et al., 2007).

In the State, there are three already identified species of Conyza that are resistant to glyphosate: C. bonariensis, C. canadensis and C. sumatrensis (Vargas et al., 2007; Lamego and Vidal, 2008; Santos et al., 2014). Even though the occurrence of glyphosate resistant Conyza sp. is restricted to merely three species (Conyza bonariensis. C. canadensis and C. sumatrensis), there is the possibility of breeding between the other species, which might result in the increase of the resistance level, as shown through the hybridization between glyphosate resistant $C$. canadensis with C. ramosissima, susceptible species (Zelaya et al., 2007). All the same, as a result from the breeding between species, morphological variations from the generated phenotypes may occur, which interfere in the herbicide-plant relation, as, for example, a greater presence of trichomes on the leaves, which may be associated to tolerance in the absorption of herbicides (Zelaya et al., 2007; Santos et al., 2014).

The incidence of new cases of herbicide resistant weeds has been increasing, reaching over 400 cases of herbicide resistant plants (Heap, 2014). Numerous factors influence in the resistance evolution, including the mutation rate and initial resistance allele frequencies in weed populations, the inheritance of the resistance and the fitness plant cost in the presence and absence of the herbicide, the type of reproduction among individuals inside the population and the range of the gene flow between populations (Jasieniuk et al., 1996). In this way, the utilization of integrated weed management practices has been related with a greater influence in the reduction of the resistance's evolution rate, especially in relation to the glyphosate resistance (Werth et al., 2008).

The genomic DNA from the seven biotypes of Conyza bonariensis was analyzed using 25 RAPD primers, in which only eight presented reproducible and high intensity polymorphisms (OPAC-12, OPA-11, OPAF-11, OPAZ-04, OPC-17, OPAC-09, OPL-05 e OPM-14) (Figure 1), where three were monomorphic (OPA-18, OPX-02 e OPAI-07) (Figure 2) and two didn't show repeatability of the polymorphisms (OPA-17 e OPA-01). Still, the other 12 RAPD primers didn't show good band amplification (OPA-02, OPA-03, OPX-03, OPX-07, OPB-3, OPB10, OPB-19, OPB-20, OPAP-04, OPM-11, OPS14 e OPAC-19). For each primer there were held two or more repetitions, and only the bands that demonstrated good repeatability and intensity were computed. The primers which amplifications didn't repeat themselves hadn't had their data registered.

The molecular analysis of the Conyza bonariensis biotypes using RAPD markers indicated that the quantity of bands formed is important to extract the most information about the biotype; the greater the polymorphism generated for each primer, the better is the information generated about the variability of the plant population. Yet, primers that generate only a few fragments are poorly informative, which makes it more difficult to study the genetic variability between species (Figure 2).

Planta Daninha, Viçosa-MG, v. 34, n. 3, p. 433-442, 2016 

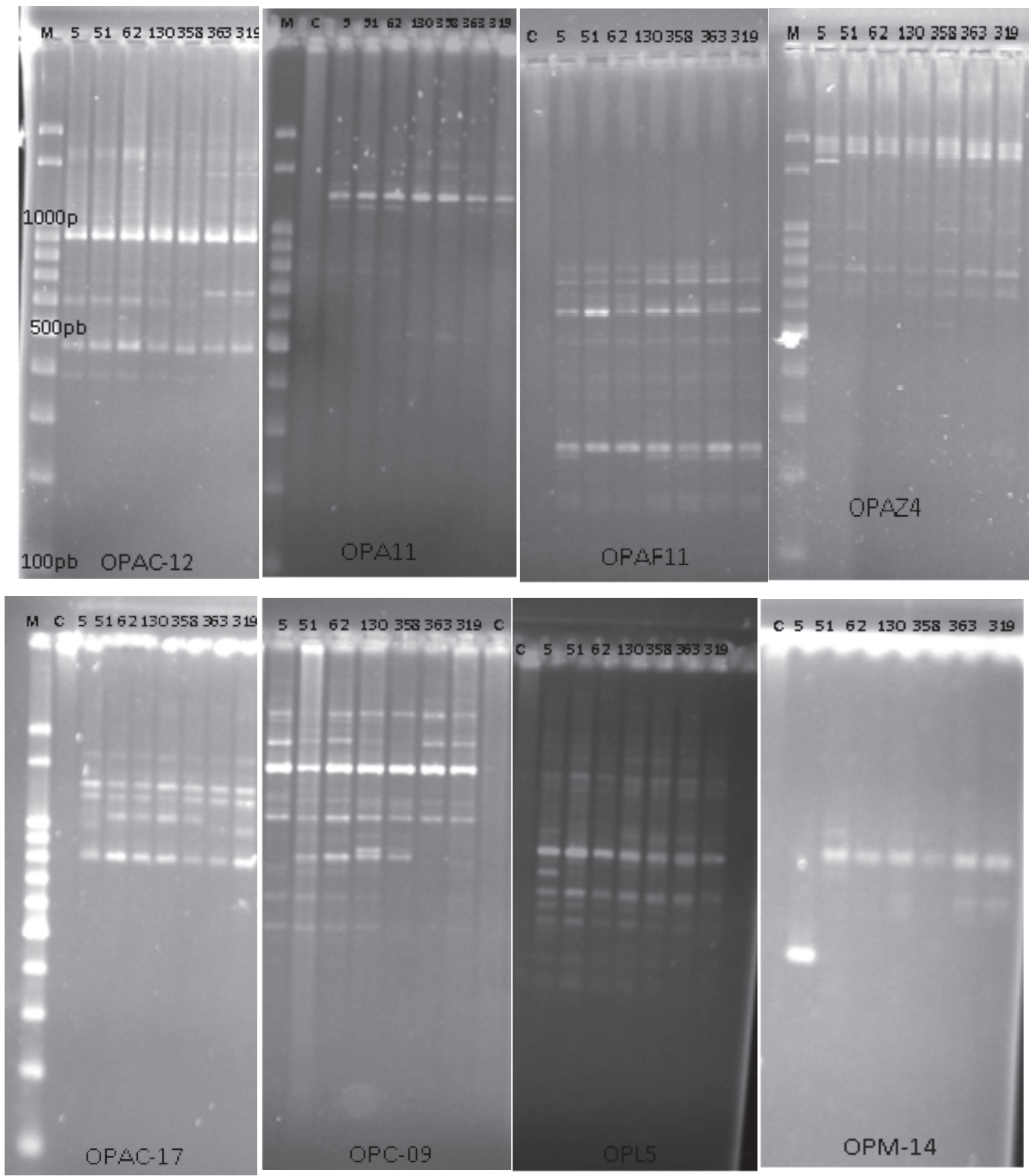

M - molecular weight marker (ladder $100 \mathrm{pb}$.) and C - control (water). Sites: 5 -Pelotas; 51 - Soledade, 62 - Guarani das Missões, 130 Cruz Alta; 358 - Caçapava do Sul; 363 - São Sepé; 319 - Piratini.

Figure 1 - Eletrophoretic profile of eight polymorphic RAPD primers in biotypes of Conyza bonariensis.

The primers result with found polymorphisms was low: about $33 \%$. This is due to the genetic proximity between the biotypes, which didn't vary in its species, or due to the low repeatability of the other primers' bands tested, a technical limitation of the RAPD. Thereby, in order to check the genetic divergence between the biotypes, the primers 


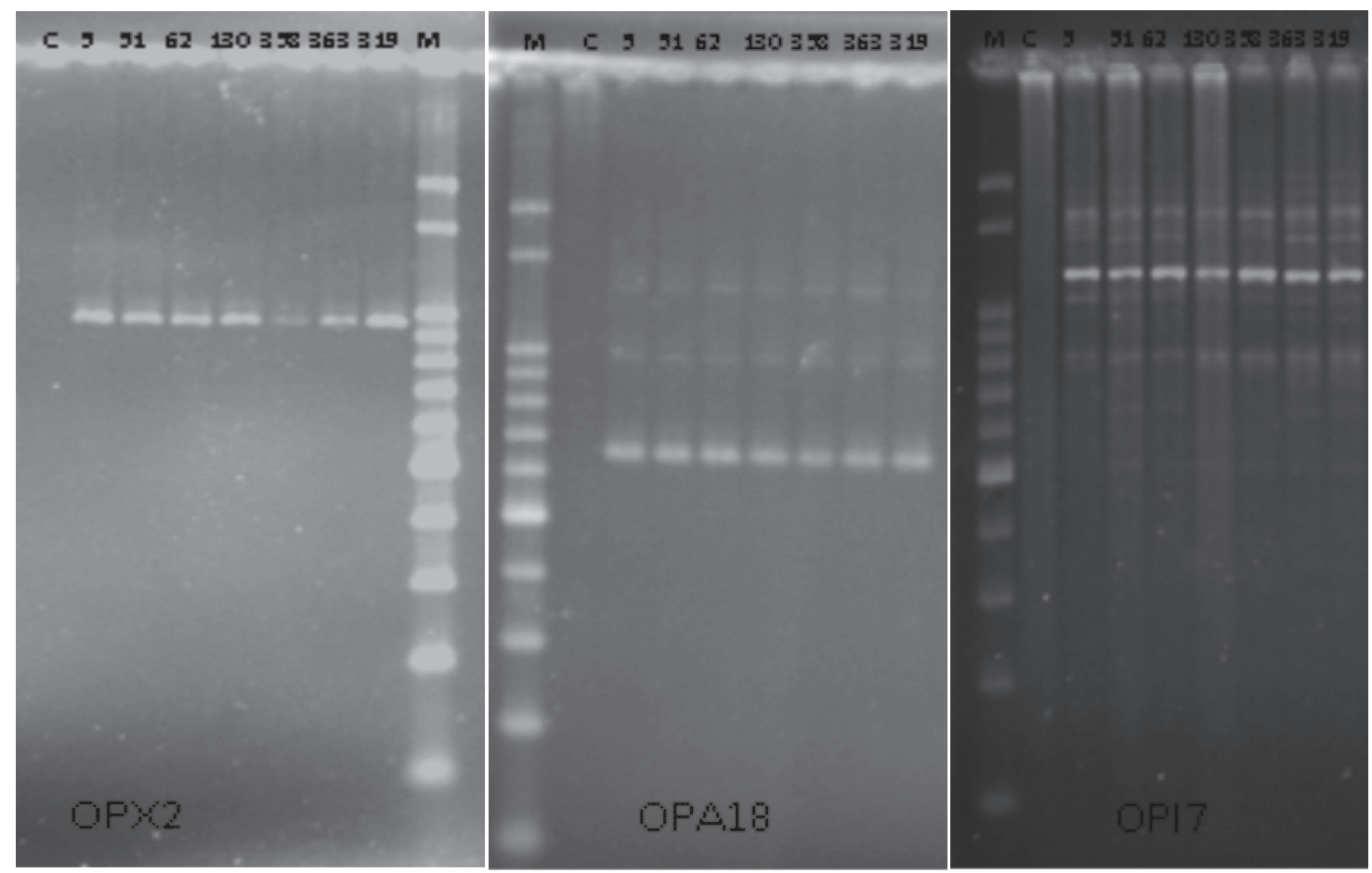

M - molecular weight marker (ladder 100 pb.) and C - control (water). Sites: 5 - Pelotas, 51 - Soledade, 62 - Guarani das Missões, 130 Cruz Alta, 358 - Caçapava do Sul, 363 - São Sepé, 319 - Piratini.

Figure 2 - Eletrophoretic profile of three monomorphic RAPD primers in biotypes of Conyza bonariensis.

OPAC-12, OPA-11, OPAF-11, OPAZ-04, OPC-17, OPAC-09, OPL-05 e OPM-14 were utilized (Figure 1).

A genetic similarity matrix with the C. bonariensis biotypes was build based in eight primers, those which presented the higher polymorphism, reproducible and of high intensity and were submitted to a Cluster analysis using the UPGMA method (Table 3). The cophenetic correlation was estimated in $r=0.86$, value that demonstrate the high reliability between the original distances matrix and the matrix generated by the UPGMA grouping. The genetic similarity matrix and the electrophoretic profile revealed a great similarity in each variety of Conyza bonariensis: the average similarity between the biotypes of the bonariensis variety (biotypes 5, 51, 62, 130 and 358 ) was of $53 \%$; the ones identified as microcephala variety (biotypes 319 and 363) was of $50 \%$; and between the varieties the polymorphisms were identical in $23 \%$. The genetic similarity of the weeds can vary between and inside the populations, which depend greatly on the target species; for instance, the results found by Roy and Ray (2009), who verified polymorphisms in Amaranthus between 52 and 18\%, were similar to those present in this study. In the studied cases, there is no relation between the geographic proximity and the genetic similarity, since biotype 5 (bonariensis variety) is similar only in 18 and $33 \%$ to the biotypes 363 and 319, respectively, which are much closer geographically. Still, biotype 5 was similar in $50 \%$ to biotypes 51 and 62, 330 and $450 \mathrm{~km}$ apart, respectively. These results were opposites to those seen by Ren et al. (2010), who verified a strong positive correlation between geographic distance and genetic diversity, that is to say, as closer the biotypes are from one another, the greater is the similarity between the biotypes of Conyza sumatrensis.

A possible explanation to a greater genetic similarity between the geographically distant biotypes may be due to the plant's capacity to disperse pollen or seeds to long distances. With 
Tabela 3 - Matrix of genetic distance between biotypes of Conyza bonariensis bases on RAPD primers

\begin{tabular}{|c|c|c|c|c|c|c|c|}
\hline Biotypes & 5 & 51 & 62 & 130 & 358 & 363 & 319 \\
\hline $5^{\frac{1}{}}$ & 1.00 & & & & & & \\
\hline 51 & 0.50 & 1.00 & & & & & \\
\hline 62 & 0.50 & 1.00 & 1.00 & & & & \\
\hline 130 & 0.38 & 0.60 & 0.60 & 1.00 & & & \\
\hline 358 & 0.23 & 0.40 & 0.40 & 0.72 & 1.00 & & \\
\hline 363 & 0.18 & 0.10 & 0.10 & 0.10 & 0.12 & 1.00 & \\
\hline 319 & 0.33 & 0.40 & 0.40 & 0.40 & 0.20 & 0.50 & 1.00 \\
\hline
\end{tabular}

1 Sites: 5 - Pelotas; 51 - Soledade; 62 - Guarani das Missões; 130 - Cruz Alta; 358 - Caçapava do Sul; 363 - São Sepé; 319 - Piratini.

that said, the dispersion of seed by man presents an important role in these genotypes dispersion, especially due to a great flow of soybean grains transportation originated in these regions, which may bring with them seeds. Still, in the last decade, a great soybean farmers migration was observed from the north to the mid-south regions of the State, which may be the source of seeds originated from these regions. In the case of Conyza sumatrensis, the seeds dispersion originated by human activities or environment disturbances have greater importance than the natural dispersion (Ren et al., 2010).

The presence of Conyza plants with resistance alleles was observed many years before the detection of the resistance in the fields, which is kept under low frequencies due to the different management ways of weeds (Okada et al. 2013). The gene flow in Conyza might produce the dissemination of resistance alleles long before the detection in the field and may also cause evolution as for the adaptability to other environments (Schwander and Leimar, 2011). Conyza bonariensis show phenotypic plasticity due to environmental variations, resulting in the misidentification through morphologic characters, just as well as a greater adaptive potential (Okada et al., 2013).

Genetic variability inside each Conyza bonariensis variety is low, which was expected, since they are the same species. This low variability may be related to a breeding predominance from the biotypes inside the population and the selective pressure with herbicides, although the differences between these two varieties may occur due to environmental characteristics, which could result in biological changes in the plants (VilaAiub et al., 2009).

From the analysis of grouping done based on the genetic similarities (Table 3), the seven biotypes were subdivided in five groups, according to the average similarity of 0.53 (Figure 3). The observed similarity value is intermediary, compared with other weeds and crops. In Bidens spp., studies have determined an average similarity of 38\% (VidaL et al., 2007) in populations from diferent sites, while for the wheat crops, the similarity was of $73 \%$, which demonstrates a high homogeneity between the individuals (Freitas et al., 2000). Plants that propagate vegitatively present higher similarity, due to the lack of genetic recombination - such as in the Eichornia crassipes case (Cardoso et al., 2002).

The dendrogram reflects that, even though the biotypes are from the same species, the RAPD markers were able to detect polymorphisms to distinguish biotypes from different regions in the State of Rio Grande do Sul (Figure 3). The UPGMA analysis based on RAPD clearly separates the biotypes named bonariensis and microcephala variaties; thus, the RAPD markers technique showed efficient to distinguish polymorphisms from Conyza bonariensis biotypes. Other markers have been used to verify the genetic diversity in weeds. For Oryza granulata, the RAPD and ISSR markers technique showed a similar power to discriminate genetic diversity (Wu et al., 2004). In the same way, Roy and Ray (2009) verified that the RAPD 


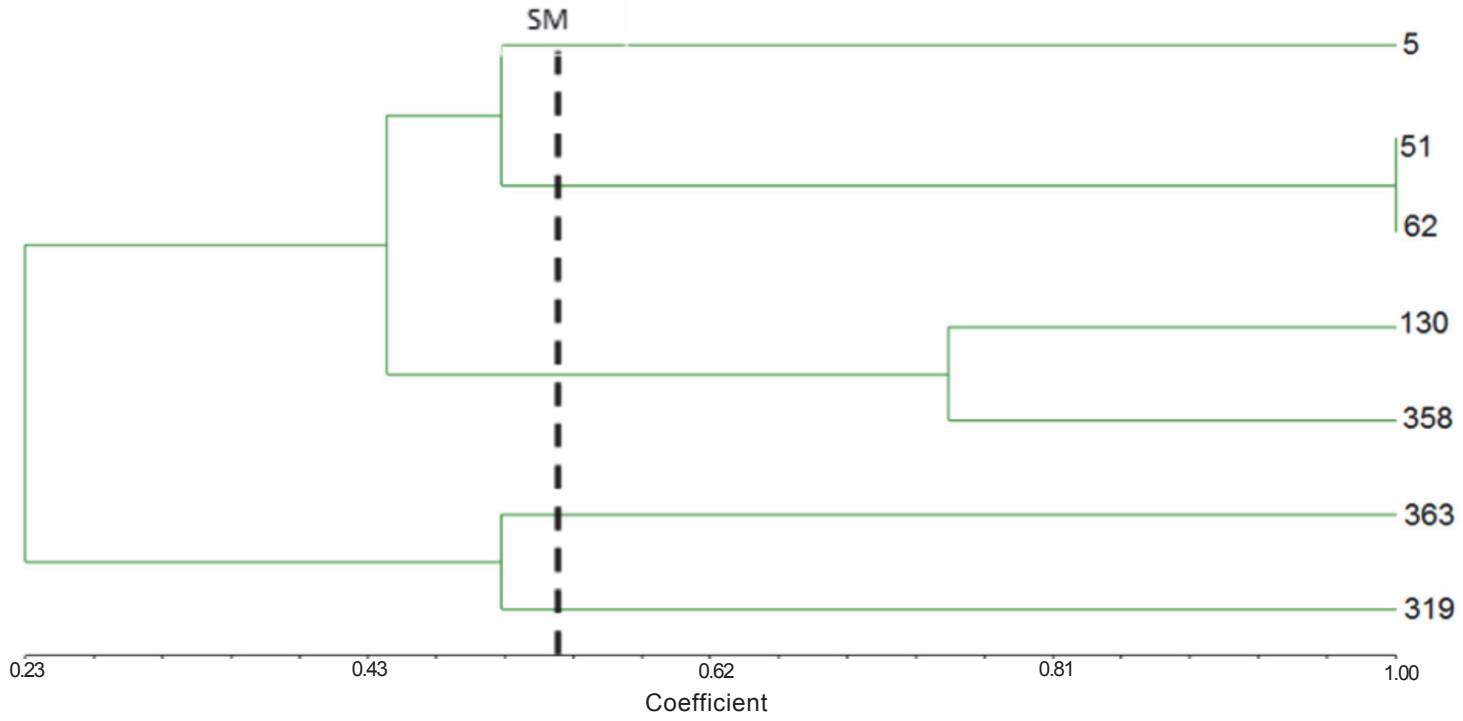

SM - average similarity. Sites: 5 - Pelotas; 51 - Soledade; 62 - Guarani das Missões; 130 - Cruz Alta; 358 - Caçapava do Sul; 363 - São Sepé; 319 - Piratini.

Figure 3 - Patterns of genetic similarity obtained between the biotypes of Conyza bonariensis, defined by the UPGMA grouping criteria, based on the Jaccard similarity.

technique was efficient in distinguishing the polymorphisms from different species of Amaranthus. In contrast, molecular ISSR markers demonstrated to be very promising in distinguishing genetic groups in Conyza sumatrensis (Ren et al., 2010). The RAPD technique presents a dominant nature and is incapable to estimate the heterozygote alleles (Afef et al., 2012). Other techniques have been user to check the genetic diversity in Conyza sp. plants using isoenzymes, wich indicated a great genetic similarity between the species C. bonariensis, C. canadensis and C. sumatrensis (Circunvis et al., 2014; Soares et al., 2015).

Species from the Conyza genus possess the ability to breed with other species from the same genus, and this might lead to phenotypic modifications that can facilitate the adaptation in different ecological niches (Zelaya et al., 2007). Besides the molecular markers to verify the diversity and characterization of weeds species, substances originated from secondary metabolism also might be used as a way of classifying species from the Conyza genus, since these substances could be connected to chromosomal changes and morphological characteristics (Urdampilleta et al., 2005).
The results indicate that all biotypes are from the same species, however Conyza bonariensis present different varieties: bonariensis and microcephala; the RAPD primers OPC-17, OPM-14, OPL-05, OPAF-11, OPA-11, OPAZ-04, OPAC-09 e OPAC-12 have the ability to genetically characterize the biotypes of Conyza bonariensis and its derivations in relation to variety; the RAPD technique might be an important tool to the genetic characterization of Conyza bonariensis.

\section{REFERENCES}

Afef B., Chokri M., Mohamed, B. Genetic structure of natural Tunisian Hypericum humifusum L. (Hypericacae) populations as assessed by allozymes and RAPDs. Ind Crops Prod. 2012;35:217-23.

Cardoso L.R. et al. Variabilidade genética de acessos de aguapé coletados no Estado de São Paulo. Planta Daninha. 2002;20:1-5.

Circunvis B.C. et al. Caracterização genética de amostras de Conyza sp. do Estado do Paraná. Planta Daninha. 2014;32:173-9.

Dekker J. Weed diversity and weed management. Weed Sci. 1997;37:237-46.

Doyle J.J., Doyle J.L. A rapid DNA isolation procedure for small quantities of fresh leaf tissue. Phytochem Bull. 1987;19:11-15. 
Entz W., Paz E.A. Caraterización de los taxa que se comercializan en Uruguay bajo el nombre de "yerba carnicera”. In: Anais $9^{\circ}$. Simpósio Latino-Americano de Farmacobotânica; $2^{\text {a }}$. Reunião Latino-Americano de Fitoquímica; 1999; Gramado. Gramado: 1999.

Ferreira P.M.A., Setubal R.B. Florística e fitossociologia de um campo natural no município de Santo Antônio da Patrulha, Rio Grande do Sul, Brasil. Rev Bras Biosci. 2009;7:195-204.

Freitas L.B. et al. Extreme homogeneity among Brazilian wheat genotypes determined by RAPD markers. Pesq Agropec Bras. 2000;35:2255-60.

Guareschi A. et al. Cytogenetics characterization of Conyza bonariensis (L.) Cronquist populations from Brazil. Ci Natura. 2012;34:39-48.

Heap I. Global perspective of herbicide-resistant weeds. Pest Manage Sci. 2014;70:1306-15.

Holt R.D., Hochberg M.E. When is biological control evolutionary stable (or is it?). Ecology. 1997;78:1673-83.

Jasieniuk M., Brûlé-Babel A.L., Morrison I.N. The evolution and genetics of herbicide resistance in weeds. Weed Sci. 1996;44:176-93.

Kissmann K.G., Groth D. Plantas infestantes e nocivas. $2^{\mathrm{a}}$. ed. São Bernardo do Campo: Basf, 1999. 825p.

Lacerda D.R. et al. A técnica de RAPD: uma ferramenta molecular em estudos de conservação de plantas. Lundiana. 2002;3:87-92.

Lamego F.P., Vidal R.A. Resistência ao glyphosate em biótipos de Conyza bonariensis e Conyza canadensis no Estado do Rio Grande do Sul, Brasil. Planta Daninha. 2008;26:467-71.

Okada M. et al. Evolution and spread of glyphosate resistance in Conyza canadensis in California. Evolut Applic. 2013;6;761-77.

Owen M.D.K. Weed species shifts in glyphosate-resistant crops. Pest Manage Sci. 2008;64:377-87.

Pagnoncelli F. et al. Diferenciação entre biótipos de Conyza sumatrensis resistentes ao glyphosate e Conyza bonariensis: comparação de características florais previamente usadas como diagnostico. In: Anais $28^{\circ}$. Congresso Brasileiro da Ciência das Plantas Daninhas; 2012; Campo Grande. Campo Grande: 2012. p.136-40.

Paula J.M. Caracterização e manejo de Conyza spp. resistente ao herbicida glyphosate [dissertação] Pelotas: Universidade Federal de Pelotas, 2009.

Ray T., Roy S.C. Genetic diversity of Amaranthus species from the indo-gangetic plains revealed by RAPD analysis leading to the development of ecotype-speciûc SCAR marker. J Hered Adv. 2009; 100:338-47.

Planta Daninha, Viçosa-MG, v. 34, n. 3, p. 433-442, 2016
Ren M.X., Li X.Q., Ding J.Q. Genetic variation and spread pattern of invasive Conyza sumatrensis around China's Three Gorges Dam. Acta Oecol. 2010;36:599-603.

Ritter M.R., Baptista L.R.M. Levantamento florístico da família Asteraceae na "Casa de Pedra" e áreas adjacentes, Bagé, Rio Grande do Sul. Iheringia. 2005;60:5-10.

Santos F.M. et al. Effect of glyphosate on the physiological parameters of horseweed. Rev Bras Cienc Agr. 2014;9:51925 .

Schneider A.A., Irgang B.E. Florística e fitossociologia de vegetação viária no município de Não-Me-Toque, Rio Grande do Sul, Brasil. Iheringia. 2005;60:49-62.

Schwander T., Leimar, O. Genes as leaders and followers in evolution. Trends Ecol Evolut. 2011;26:143-51.

Soares A.A.F. et al. Evidence of high gene flow between samples of horseweed (Conyza canadensis) and hairy fleabane (Conyza bonariensis) as revealed by isozyme polymorphisms. Weed Sci. 2015;63:604-12.

Vargas L. et al. Buva (Conyza bonariensis) resistente ao glyphosate na região sul do Brasil. Planta Daninha. 2007;25:573-8

Vargas L. et al. Resistência de plantas daninhas a herbicidas. Viçosa, MG: Leandro Vargas, 1999. 131p.

Vidal, R.A. et al. Análise genética de genótipos de Bidens pilosa através da técnica RAPD. Sci. Agr., v.8, n.4, p.399403, 2007.

Vila-Aiub M.M., Neve P., Powles S.B. Fitness costs associated with evolved herbicide resistance alleles in plants. New Phytol. 2009; 184:751-67.

Werth J.A. et al. Managing the risk of glyphosate resistance in Australian glyphosate resistant cotton production systems. Pest Manage. Sci. 2008;64:417-21.

Williams J.G.K. et al. DNA polymorphisms ampliûed by arbitrary primers are useful as genetic markers. Nucleic Acids Res. 1990;18:6531-5.

Winkler L.M., Vidal R.A., Barbosa Neto J.F. Caracterização genética de Euphorbia heterophylla resistente a herbicidas inibidores da acetolactato sintase. Pesq Agropec Bras. 2003;38:1067-72.

$\mathrm{Wu}$ C. et al. Genetic diversity among and within populations of Oryza granulata from Yunnan of China revealed by RAPD and ISSR markers: implications for conservation of the endangered species. Plant Sci. 2004;167:35-42.

Zelaya I.A. et al. Transfer of glyphosate resistance: evidence of hybridization in Conyza (Asteraceae). Am J Bot. 2007;94:660-73. 